\title{
Poetic Vs. Poetical Translation of Poetry (English-Arabic)
}

\author{
Ghazala, H. S. \\ Department of English, College of Social Sciences \\ Umm Al-Qura University \\ Makkah Al-Mukarramah, Saudi Arabia
}

\begin{abstract}
The translation of poetry has been and will continue to be an issue of great concern to translators, men of letters and readers. Poetry has been approached differently by translators. They are divided into two major parties: tone insists on translating poetry into poetry with respect to all prosodic features; another suggests translating sense with no concern in prosody, especially rhyme, rhm, meter and foot, especially when the translator is for some good reason, unable to translate a poem into a poen in the target language(TL). Each party has their own justifications for their claim. This Paper attempts to demonstrate the merits and demerits of both approaches at translating one and the same poem in terms of poetic translation for the former, and poetical translation for the latter. The aim behind that is two fold: first to satisfy all types of readers; second, to provide concrete evidence for the argument put forward throughout the whole Paper, which is poetic translation is superceding poetical translation in Arabic for Arab readers who still highly appreciate the aestheticity and poeticity of poetry. At the end of the day, it is left to readers to decide which version to prefer. At times, more than one poetic version of translation are suggested for the same poem by different translators. Still on one or two occasions, a middle way version combining some features of each of poetical and poetic translations, is proposed. It is termed as a 'semi-poetic' translation, with the ultimate objective of drawing a comparison between the different versions of translation of the same poem to give readers the opportunity to judge for themselves which translation they go for and why. Convincing readers is a daunting ask, but rewarding at the end. This pproach is applied to the translation of five English poems into Arabic.
\end{abstract}

Key words: Foot, poetry, poetic, poetical, prosodic features, rhyme, rhythm, translation

Cites as: Ghazala, H. S. (2019). Poetic Vs. Poetical Translation of Poetry (English-Arabic). Arab World English Journal for Translation \& Literary Studies, 3 (1) 3- 21.

DOI: http://dx.doi.org/10.24093/awejtls/vol3no1.1 